\title{
A historical overview of leprosy epidemiology and control activities in Amazonas, Brazil
}

\author{
Carolina Cunha[1], Valderiza Lourenço Pedrosa ${ }^{[1]}$, Luiz Carlos Dias ${ }^{[1]}$, Andréa Braga ${ }^{[2]}$, \\ Anette Chrusciak-Talhari ${ }^{[2],[5],}$ Mônica Santos ${ }^{[1],[5], ~ G e r s o n ~ O l i v e i r a ~ P e n n a ~}{ }^{[3]}$, \\ Sinésio Talhari ${ }^{[4]}$ and Carolina Talhari ${ }^{[1],[5]}$
}

\begin{abstract}
[1]. Departamento de Dermatologia, Fundação de Dermatologia e Venereologia Alfredo da Matta, Manaus, AM. [2]. Departamento de Dermatologia, Fundação de Medicina Tropical Dr Heitor Vieira Dourado, Manaus, AM. [3]. Departamento de Dermatologia, Centro de Medicina Tropical, Universidade de Brasília, Brasília, DF. [4]. Departamento de Dermatologia, Universidade Nilton Lins, Manaus, AM. [5]. Programa de Pós-Graduação em Medicina Tropical , Universidade do Estado do Amazonas, Manaus, AM.
\end{abstract}

\begin{abstract}
Leprosy is an ancient infectious disease caused by Mycobacterium leprae. According to comparative genomics studies, this disease originated in Eastern Africa or the Near East and spread with successive human migrations. The Europeans and North Africans introduced leprosy into West Africa and the Americas within the past 500 years. In Brazil, this disease arrived with the colonizers who disembarked at the first colonies, Rio de Janeiro, Salvador and Recife, at the end of the sixteenth century, after which it was spread to the other states. In 1854, the first leprosy cases were identified in State of Amazonas in the north of Brazil. The increasing number of leprosy cases and the need for treatment and disease control led to the creation of places to isolate patients, known as leprosaria. One of them, Colonia Antônio Aleixo was built in Amazonas in 1956 according to the most advanced recommendations for isolation at that time and was deactivated in 1979. The history of the Alfredo da Matta Center (AMC), which was the first leprosy dispensary created in 1955, parallels the history of leprosy in the state. Over the years, the AMC has become one of the best training centers for leprosy, general dermatology and sexually transmitted diseases in Brazil. In addition to being responsible for leprosy control programs in the state, the AMC has carried out training programs on leprosy diagnosis and treatment for health professionals in Manaus and other municipalities of the state, aiming to increase the coverage of leprosy control activities. This paper provides a historical overview of leprosy in State of Amazonas, which is an endemic state in Brazil.
\end{abstract}

Keywords: Leprosy. Historical overview. Amazonas.

\section{INTRODUCTION}

Leprosy is a chronic infectious disease caused by Mycobacterium leprae. It mainly affects the skin and peripheral nervous system. Depending on the type of leprosy, involvement of the reticuloendothelial system, bones and joints, mucous membranes, eyes, testes, muscles, adrenals and other areas may occur ${ }^{(1)}$. Transmission occurs between humans through prolonged and close contact, and untreated patients present with the multibacillary types of the disease ${ }^{(2)}$. Aerosol spread of nasal discharge and uptake through the nasal or respiratory mucosa are likely the principal modes of transmission ${ }^{(3)}$. The nose and respiratory system are not only the ports of exit but are also regarded as the main ports of entry for this disease ${ }^{(4)}$. Transmission is assumed to occur directly from an infected

Corresponding author: Dra. Carolina Talhari. Fundação Alfredo da Matta. Rua Codajás 24, Cachoeirinha, 69065-139 Manaus, AM.

Phone/Fax: 5592 3632-5853

e-mail: carolinatalhari@gmail.com

Received 9 May 2014

Accepted 12 September 2014 person to another person; however, indirect routes cannot be ruled out because there is evidence that $M$. leprae remains viable for some time outside of the human body ${ }^{(5)}$. Nine-banded armadillos and African monkeys, including chimpanzees, sooty mangabeys, and cynomolgus macaques, are the only animals other than humans that can be naturally infected with M. leprae $e^{(6)}$; however, there is no evidence that they could be involved in its transmission chain ${ }^{(7)}$.

Clinically, this disease manifests with localized, multiple or disseminated lesions. The histopathology of the skin lesions varies from compact granulomas to diffuse infiltration of the dermis, largely depending on the immune status of the patient. In some patients, histopathological examination findings may not be correlated with the clinical diagnosis ${ }^{(1)}$.

The initial leprosy treatment was lifetime monotherapy with dapsone. Later, a combination of dapsone and rifampicin was used. However, due to the problem of dapsone resistance detected in more than 40 endemic countries, including the State of Amazonas ${ }^{(8)}$ during the 1970s and 1980s, in October 1981, the World Health Organization (WHO) recommended the introduction of a new therapeutic regimen known as the multidrug therapy (MDT), which included dapsone, rifampicin and clofazimine ${ }^{(9)(10)}$. 
Following the success of MDT and a steady decline in the number of registered patients, in 1991, the WHO adopted a resolution calling for the elimination of leprosy as a public health problem by the year 2000. The goal was to reduce the known prevalence of leprosy to below 1 patient per 10,000 inhabitants ${ }^{(11)}$. Leprosy was eliminated at the global level by the year 2000. However, most endemic countries had not reached this elimination goal at that time. Then, a new goal was established for elimination by 2005. By the year 2005, Brazil was among nine countries that had not eliminated leprosy as a public health problem, and its prevalence in this country was still over 1/10,000 inhabitants.

According to the WHO, 219,075 new leprosy cases were detected worldwide in 2011. Among the countries that submitted reports to the WHO in 2011, India, Brazil and Indonesia reported $83 \%$ of these new cases $(58 \%$ in India, $16 \%$ in Brazil and $9 \%$ in Indonesia). India and Brazil have experienced very gradual declines in the prevalence of this disease since 2006 and 2007, respectively. In addition, after maintaining a plateau since 2006, Indonesia experienced a significant increase in new cases in $2011^{(12)}$.

According to the Brazilian Ministry of Health (BrMoH), 33,955 new leprosy cases were detected in Brazil in 2011, representing a general detection rate of 17.6/100,000 inhabitants. The leprosy prevalence in Brazil decreased from 4.52/10,000 population in 2003 to $1.56 / 10,000$ inhabitants in $2010^{(13)}$. However, according to a study conducted by Penna and Penna in 2007, this disease will remain a public health problem until the year $2020^{(14)}$.

According to the $\mathrm{BrMoH}, 643$ leprosy cases were detected in 2011 in the State of Amazonas. Of them, 586 (84.4\%) were new cases, 66 (9.5\%) were relapses, 34 (4.9\%) were defaulters and $8(1.2 \%)$ were transferred from other states. Among the new leprosy cases detected, 256 (45.9\%) were from the capital, Manaus, and 317 (54.1\%) were from other municipalities of State of Amazonas. The leprosy prevalence in the Amazonas showed a decreasing trend from 1987 to 2011, achieving a 98\% reduction (from 123.95/10,000 to 2.97/10,000 inhabitants) ${ }^{(13)}$.

At the Alfredo da Matta Center (AMC) for Tropical Dermatology and Sexually Transmitted Diseases which is a referral center for the diagnosis and treatment of leprosy in the State of Amazonas, 329 leprosy cases were detected in 2011. Of them, $256(77.8 \%)$ were new cases, 41 (12.5\%) were relapses, $23(7 \%)$ were defaulters and $9(2.7 \%)$ were transferred from other municipalities. The 256 new cases detected at the AMC corresponded to $43.7 \%$ of the reported cases in State of Amazonas and $79.5 \%$ of the cases reported in the capital of Manaus ${ }^{(15)}$. These data indicate that there is an urgent need to implement even more decentralization activities and/or to perform more training and supervision throughout the whole state.

\section{HISTORY OF THE DISEASE IN THE STATE OF AMAZONAS}

According to comparative genomics studies, leprosy originated in Eastern Africa or the Near East and spread with successive human migrations. Europeans and North Africans introduced leprosy into West Africa and the Americas within the past 500 years $^{(16)}$. In Brazil, the disease arrived with the colonizers who established the first colonies, Rio de Janeiro, Salvador and Recife, at the end of the sixteenth and beginning of the seventeenth centuries, and it was then spread to the other states. Within years, increasing numbers of patients were observed in the provinces of Bahia, Minas Gerais, Pará, Pernambuco, Rio de Janeiro and São Paulo, where agriculture was the most important economic activity ${ }^{(17)}$.

In the State of Amazonas, the first records of patients diagnosed with leprosy are from $1854^{(17)}$. In approximately 1877 , the great drought in northeast Brazil caused one of the largest human migrations in the country. Rubber extraction was an important activity in the Amazon region at that time, resulting in an increasing demand for manpower. Many northeastern immigrants came to work in this region. Later, during the Second World War, more northeastern immigrants arrived in this region for work. They were known as rubber soldiers. Similar to other states of the Brazilian Amazon basin, rubber extraction in the State of Amazonas was commercially more important in the Amazon River and its whitewater tributaries, such as Jurua, Purus, and Madeira River, among others. Historically, the highest number of patients diagnosed with leprosy lived on the banks of these rivers. However, the communities living on the Negro river, which is a blackwater river, and its tributaries always contained a lower number of leprosy patients. Rubber extraction was never economically important in the Negro river region. Therefore, it is possible that the rubber soldiers and their families contributed to the introduction and augmentation of the number of leprosy patients in the Amazon Basin ${ }^{(18)(19)}$.

The increasing number of new cases of this disease in State of Amazonas and the need for treatment and disease control led authorities to follow national recommendations and create special places to isolate leprosy patients. In 1913, after a boat expedition throughout the Amazonas Valley, Oswaldo Cruz reported a high number of leprosy patients living among the healthy population ${ }^{(20)}$. The compulsory isolation policy was defended by all local medical elite specialists and also by the Amazonas population. Moreover, this measure was undertaken in other states of Brazil during the 1910s following a worldwide movement to combat leprosy. Umirisal, which was built in 1908, was initially used for the isolation of patients with smallpox. However, after the development of a vaccine and disease control, it was used to house leprosy patients. In 1920, Alfredo da Matta, a sanitary rural inspector of leprosy and venereal diseases, estimated that there were 800 to 1,000 leprosy patients in the state $^{(21)}$. Umirisal was no longer sufficient to house all of the patients. Thus, a new leprosarium, Paricatuba, was built on the riverbanks of the Negro River ${ }^{(17)(22)}$.

On April 26 $6^{\text {th }}$, 1922, a daycare called Alice Sales was established in the neighborhood of Cachoerinha in Manaus to assist the children of leprosy patients. At that time, some segregationist control measures had already been adopted involving household contacts, and the children of patients were separated from their parents at birth. The Educandário Gustavo Capanema was another daycare institution built to support the 
children of leprosy patients in Manaus. This segregation was considered necessary to break the transmission chain in families. Thus, thousands of families were destroyed; leprosy patients were sent to leprosaria, and children were separated from their families ${ }^{(17)(22)}$.

In 1934, a large national crusade to control leprosy was initiated. The State of Amazonas was also involved, and local action was supervised by Alfredo da Matta. Throughout his career, he wrote several documents emphasizing the importance of leprosy in State of Amazonas. Apparently, the national leprosy control committee did not realize how serious the leprosy situation was in this state ${ }^{21}$.

In 1965, the leprosy patients isolated at Paricatuba leprosarium were transferred to a new place, named Colonia Antônio Aleixo. This leprosarium was built according to the most advanced recommendations for isolation at that time ${ }^{(17)(22)}$.

On March $12^{\text {th }}, 1966$, by the request of the Amazonas State Health Administration, the Franciscan Missionaries of Mary, an organization of the Catholic Church, began working in a new leprosarium to provide care and support for leprosy patients $^{(23)}$. Due to alarming reports by the newspapers and radios at that time of the indifference of authorities to leprosy, the local government, with the support of the $\mathrm{BrMoH}$, the WHO and international funding, began offering better assistance to patients ${ }^{(24)}$. Between 1974 and 1975, a multidisciplinary medical team composed of dermatologists (Sinésio Talhari, Mario Ewerton and Maria da Graça Cunha), an ophthalmologist (Eugênio Aubert), an orthopedist (Leonildo Rodrigues) and an otorhinolaryngologist (Renato Telles) began working at Colônia Antônio Aleixo ${ }^{(22)}$, and the total population of approximately 1,600 leprosy patients was reduced to less than 650 patients.
At that time, several treated and cured patients who were still living in the leprosarium were also released ${ }^{(18)}$.

Currently, there is a small community living around the ruins of the main buildings of the Paricatuba leprosarium ${ }^{(22)}$. The area of the Colonia Antônio Aleixo leprosarium became a neighborhood of Manaus with an estimated population of 18,000 inhabitants ${ }^{(25)}$.

The history of the AMC parallels the history of leprosy in the state. In 1954, due to the success obtained with the use of sulfone, the Brazilian Government allocated funds for the installation of leprosy dispensaries in the region. In August 1955, the Alfredo da Matta Dispensary was inaugurated in Manaus $^{(22)}$. Progressively, the Alfredo da Matta Dispensary intensified and expanded its outpatient activities, and after 1975, it became a center for dermatological and sexually transmitted diseases. On November $24^{\text {th }}, 1982$, the dispensary was officially recognized as the AMC and took responsibility for the management of the Amazonas leprosy control program. More dermatologists, physiotherapists, nurses, and health technicians were recruited. Intense leprosy control activities in Manaus and other municipalities of the state started began these changes. Figure 1 shows the increasing number of new patients diagnosed and the improvement of the quality of the sustainable leprosy control program after the implementation of MDT, which was a new therapeutic regimen for leprosy recommended by the WHO in $1981^{(9)}$. The State of Amazonas was one of the first Brazilian States to implement MDT. In 1982, it was initiated at the AMC as a standard therapy for leprosy, mainly because sulfone resistance had already been confirmed in leprosy patients from Colônia Antônio Aleixo ${ }^{(8)}$. In addition to the $\mathrm{AMC}$, the implementation of MDT by other health centers in Manaus that

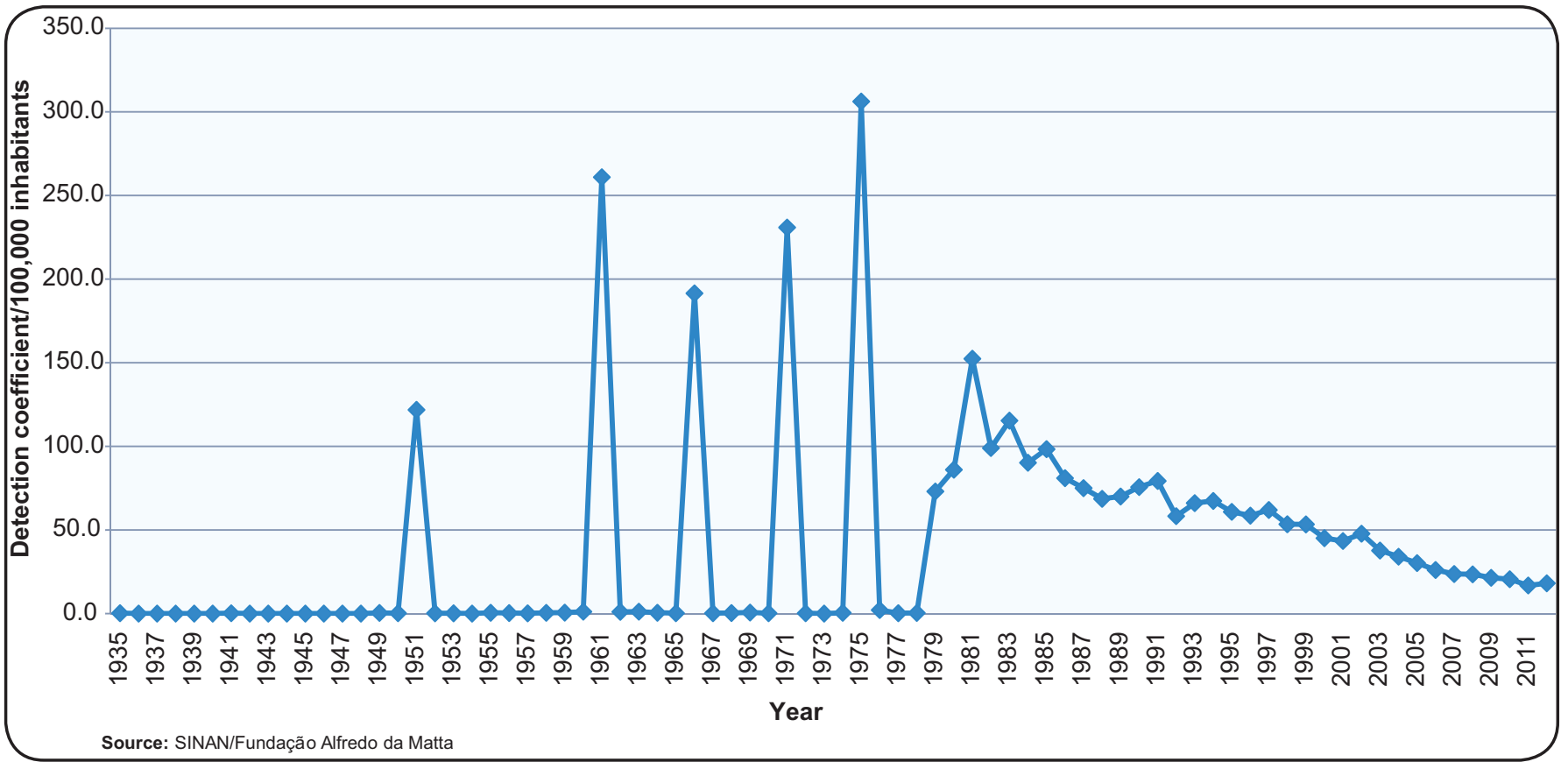

FIGURE 1 - New leprosy cases detected in the State of Amazonas from 1935-2012. 
participated in the program and centers from other municipalities of the State of Amazonas were initiated in 1985. Amazonas is the largest Brazilian state by area $\left(1,570,745,600 \mathrm{~km}^{2}\right)$, with an estimated population in 2013 of 3,807,921 inhabitants. Manaus, which is the capital, is secluded by a rain forest, and transportation to other municipalities occurs mainly by boat or airplane ${ }^{(25)}$. Despite the efficacy and widespread use of MDT in the Amazonas, most of the municipalities are very large in size, and one of the main difficulties encountered by patients is the time spent traveling from rural zones to town centers for monthly MDT supervision. Therefore, leprosy control has proven to be challenging in this region due to difficulties in reaching the high endemic areas of the state. Over the years, training programs for health professionals have been conducted regularly in Manaus and in other municipalities of the state that include regular 5-10 day courses on the general aspects of the disease and MDT led by AMC staff(26).

The AMC still facilitates the diagnosis, treatment, and prevention of leprosy disabilities and provides rehabilitation services, and it has became one of the best training centers for leprosy, general dermatology and sexually transmitted diseases in Brazil. Additionally, the center is a national and WHO referral center for the diagnosis and treatment of leprosy.

\section{EPIDEMIOLOGICAL TRENDS IN THE STATE OF AMAZONAS}

In the period prior to the deactivation of the leprosy colonies, there was a fluctuation in the detection of rate data, which was likely because the quality of the routine case detection data was not sufficient to ensure for consistency and comparability within a period time series (Figure 1). After the eradication of the leprosaria in the State of Amazonas, the leprosy data became more consistent. Analysis of the period time series revealed increases in the detection rate over the years. From the early 1980 s, the rate increased up to $77 \%$, and changes over time were observed. Since 2000, the disease has behaved in a more stable manner, with a decreasing trend in the detection rate; for example, in the State of Amazonas, it dropped from $45.1 / 100,000$ to $18.1 / 100,000$ inhabitants in 2012, representing a decrease of $59.8 \%$. According to the $\mathrm{BrMoH}$ parameters, the state remained hyperendemic $(\geq 40.0 / 100,000$ inhabitants) until 2002, despite the important reduction in detection. Figure 2 shows that in 2003, the state showed a very high coefficient of endemicity (40.0- 20.0/100,000 inhabitants), which currently remains high (20.0- 10.0/100,000 inhabitants) ${ }^{(15)}$.

The detection rate in children under 15 years of age in the Amazonas was very high and showed an unstable pattern, similar to the overall rate (Figure 3). In endemic areas such as the State of Amazonas, children are exposed to leprosy bacillus at an early age; thus, intense transmission increases the occurrence of leprosy cases in this specific population. Therefore, the leprosy detection rate in children under 15 years is an indicator of transmissibility and determines the trend of endemicity, reflecting the severity of an endemic. In recent years, this coefficient has declined. However, according to the $\mathrm{BrMoH}$ parameters, the state remained at hyperendemic levels until 2004 ( $\geq 10.0 / 100,000$ inhabitants), with high detection rates in children. From 2005, there was a very high level of endemicity (10.0- 5.0/100,000 inhabitants). According to a historical data series from the $1990 \mathrm{~s}$, the state showed a decreasing trend in detection rates, from 35.2/100,000 inhabitants in 1990 to $5.8 / 100,000$ inhabitants in 2012. Although this rate was reduced by $83.5 \%$, the state still shows high leprosy detection rates among children ${ }^{(15)}$.

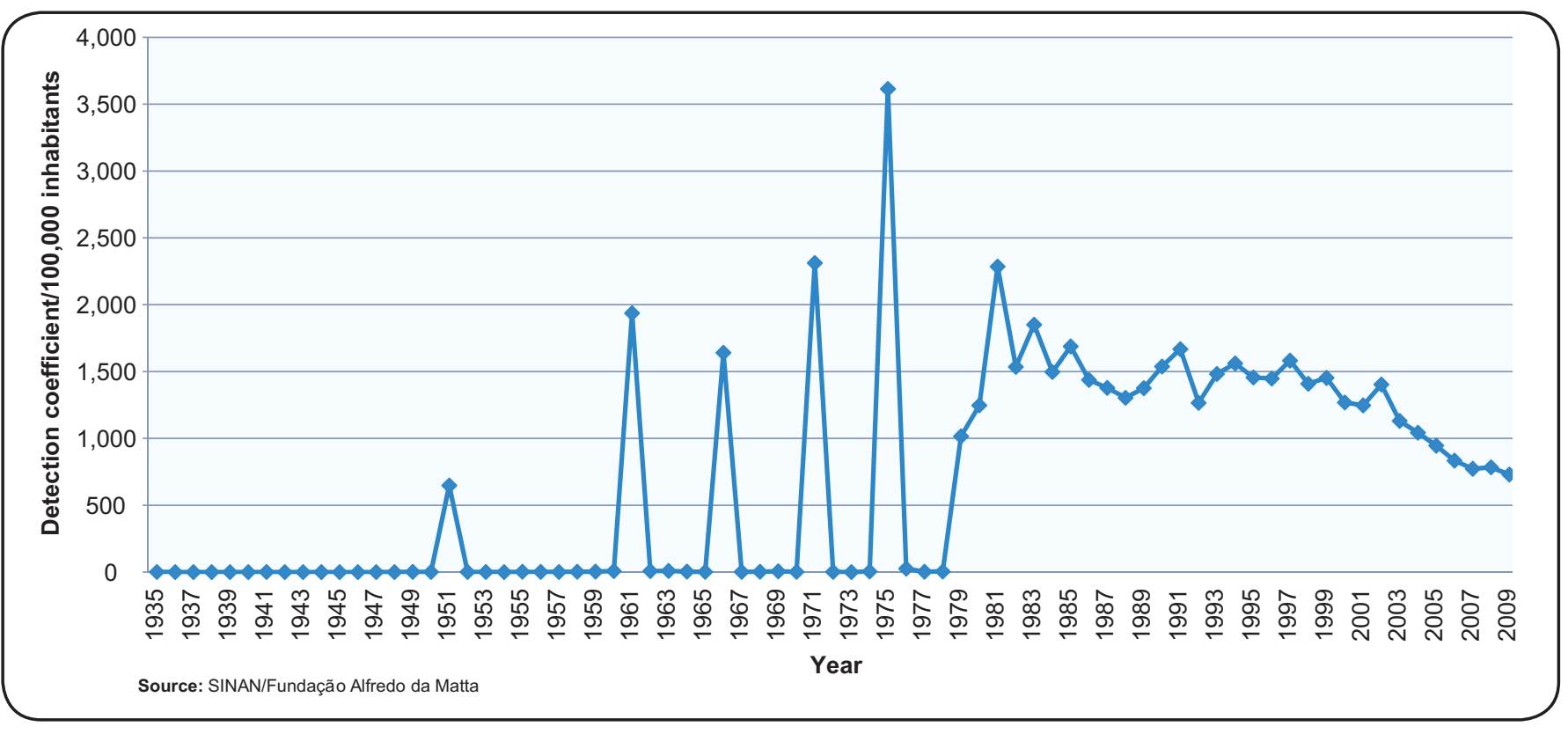

FIGURE 2 - Leprosy detection coefficients in State of Amazonas from 1935-2012. 


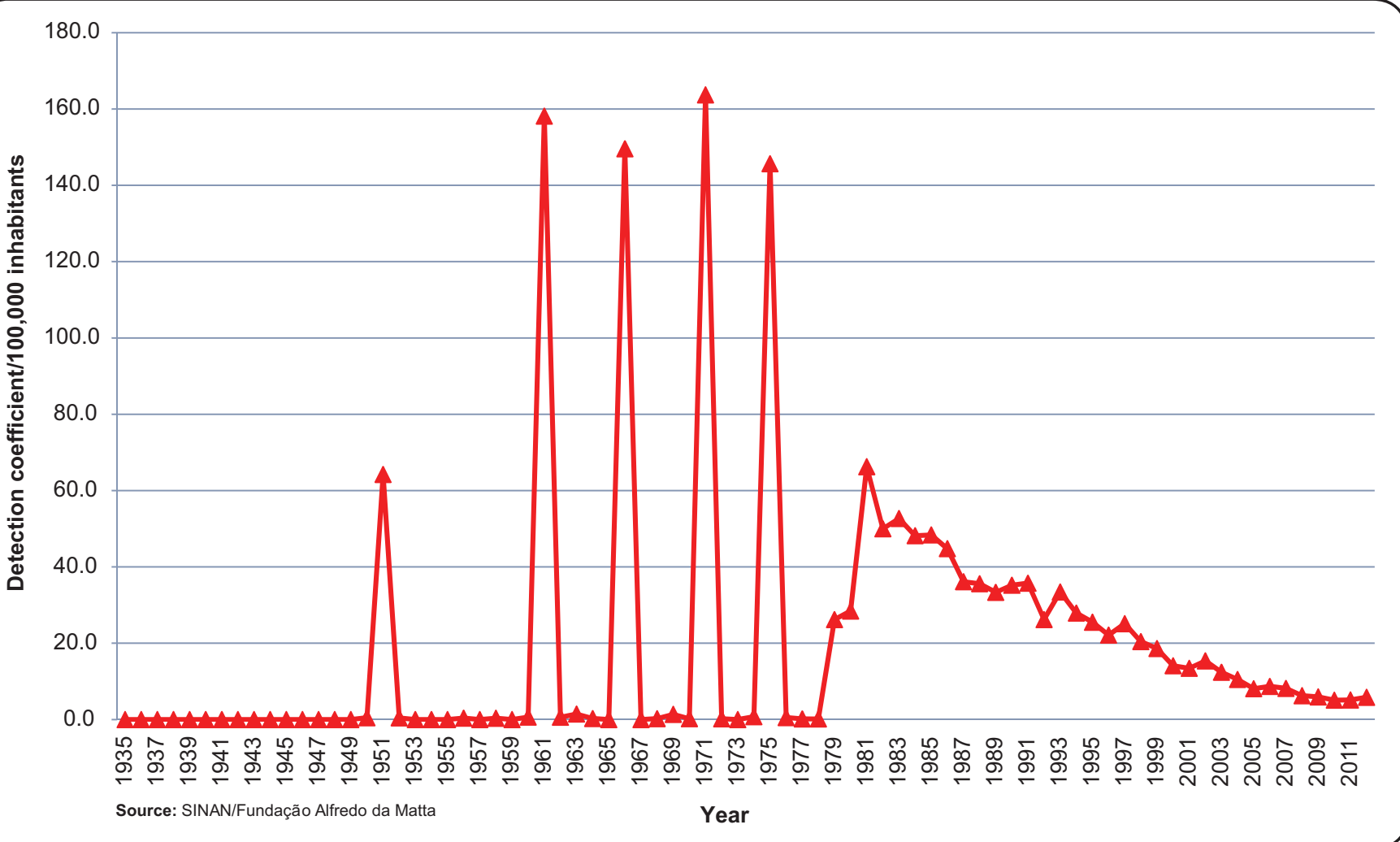

FIGURE 3 - Leprosy detection rates among children in the State of Amazonas from 1935-2012.

In 1978, the leprosy prevalence in the State of Amazonas (Figure 4) was 79.8/10,000 inhabitants, increasing gradually until 1988, when it reached the highest level of the entire historical data series of 129.0/10,000 inhabitants. During this period, despite the introduction of MDT, the number of patients released from the registry was small due to long treatment courses and the national guidelines for releasing leprosy cases for cured or defaulter patients. At this time, the predominant treatment was not MDT, and patients undergoing other therapies, depending on the clinical form, remained under surveillance after treatment indefinitely. Even those who were under MDT and finished treatment were kept on the registry for years.

Despite the abovementioned operational problems, the introduction of MDT in the State of Amazonas led to a tremendous decrease in leprosy prevalence from 129/10,000 inhabitants in 1988 to $2.8 / 10,000$ inhabitants in 2012 (Figure 4). This reduction of $97.8 \%$ also occurred due to the application of revised national guidelines related to the release of defaulters from the registry. These regulatory measures have been altered over the years, resulting in shorter treatment times, the abolition of post-treatment follow-up and a shorter duration for the removal of defaulter patients from the active record. Therefore, although the prevalence data generated are useful for monitoring leprosy elimination, they may not reflect the actual epidemiological situation of the disease because they are strongly influenced by operational issues ${ }^{(26)(27)}$.
In 2012, an increasing number of new cases of leprosy were diagnosed in several municipalities of Amazonas state as part of an active case-finding program conducted by dermatologists and healthcare personnel from the $\mathrm{AMC}^{(28)}$. In many municipalities, the number of cases diagnosed by the AMC staff in only one visit was higher than the total number of cases diagnosed in the previous months (Table 1). These data demonstrate that underdiagnosis occurs in the State of Amazonas. Moreover, it indicates that at least in these municipalities, leprosy transmission is still an important issue.

According to the present situation, there are two possible explanations for the reductions in the prevalence and incidence of this disease in the State of Amazonas: 1) although it is still an endemic state, the current reduction of new cases points towards a decrease in leprosy transmission as a direct consequence of MDT implementation; or 2) underdiagnosis might be occurring due to a decrease in leprosy control program activities in the health centers of the capital and other municipalities of the State of Amazonas. Analysis of recent data obtained in different municipalities of the State of Amazonas suggests the possibility of underdiagnosis and the necessity of intensifying training and supervision activities.

\section{PERSPECTIVES AND CONCLUSIONS}

Many facts have been reported in the literature in the remote history of leprosy, ranging from its identification as an incurable disease considered as God's punishment to the possibility of a 
TABLE 1 - Leprosy cases diagnosed by the Alfredo da Matta staff in 2012 in the municipalities of the State of Amazonas.

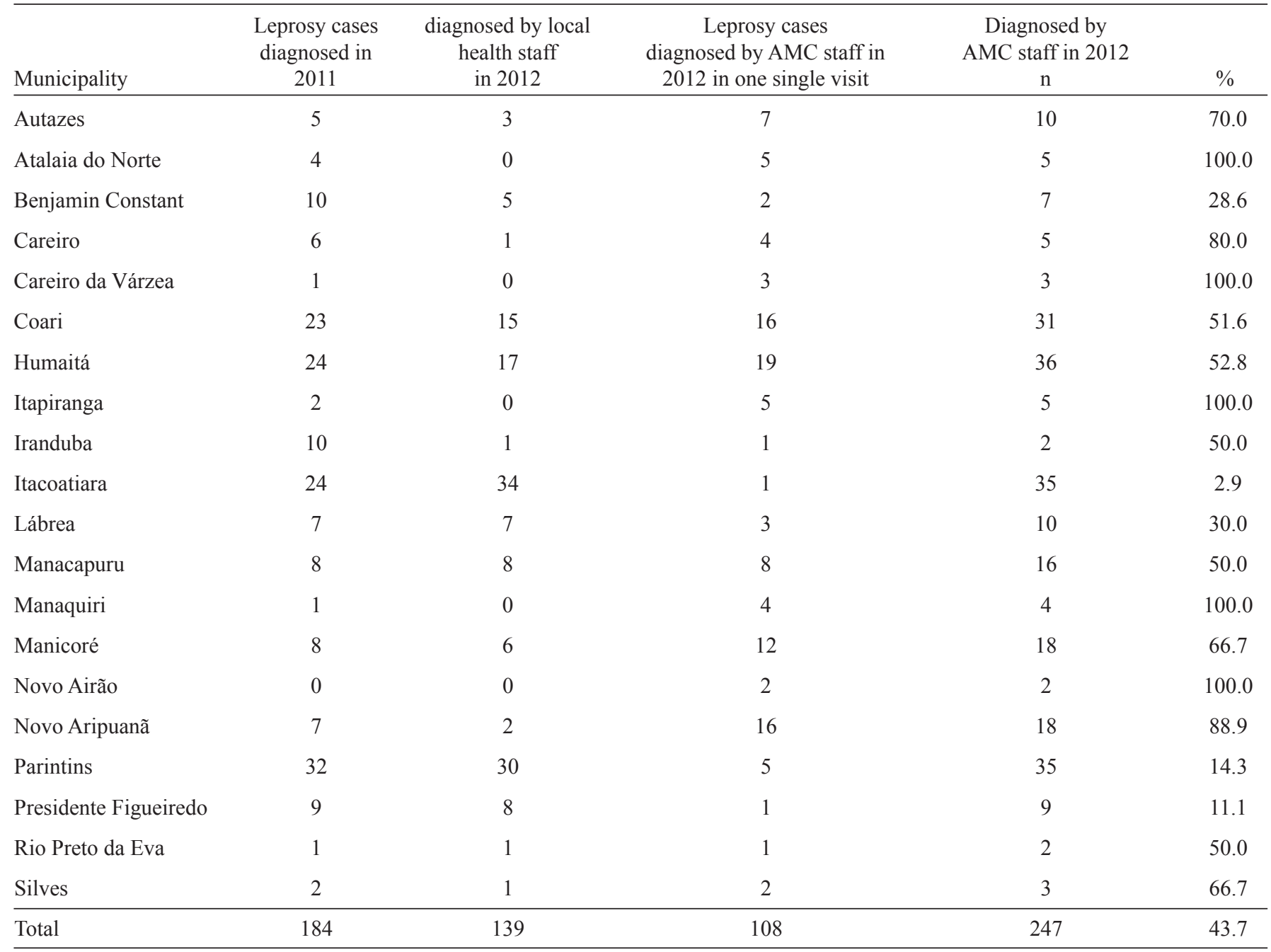

AMC: Alfredo da Matta Center.

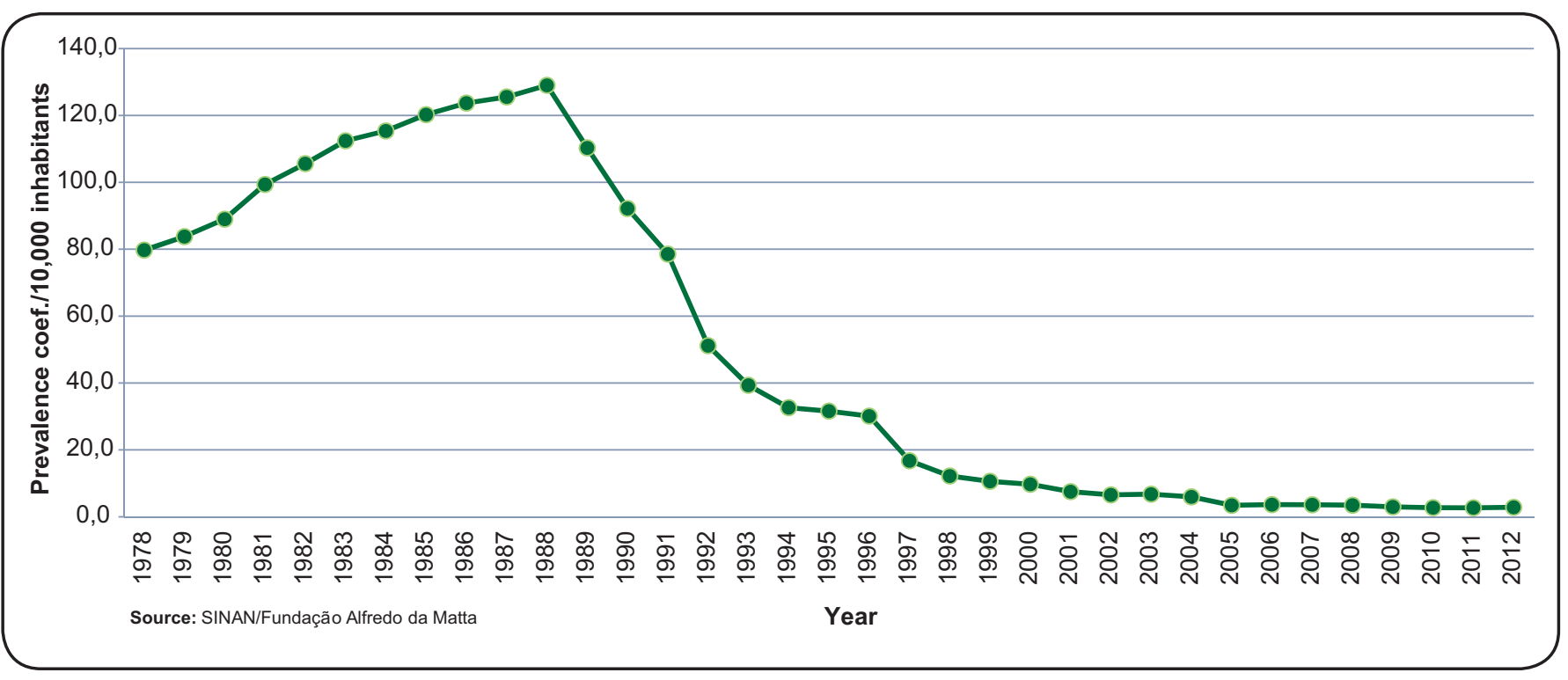

FIGURE 4 - Leprosy prevalence coefficients in State of Amazonas from 1978-2012. 
single-dose treatment for some patients. The decoding of the M. leprae genome ${ }^{(29)}$ has introduced a broad new field of research and has led to an increased understanding of the involvement of genetics in the pathophysiology of this disease ${ }^{(30)}$.

Despite these advances, many old doubts and questions remain unanswered, and there is much to learn and teach clinicians with regard to how to diagnose and manage leprosy patients $^{(31)(32)(33) \text {. }}$.

The data presented in this paper clearly show that decentralization as defined by the $\mathrm{BrMoH}$ did not occur in the state despite all of the efforts of the AMC staff. The institution is one of the few in the world that can provide important information on this disease by performing high-quality research. It is essential that the AMC continues to provide assistance to most of the patients from Manaus; therefore, decentralization is not an effective strategy to achieve the goals of this institution because the goals cannot be reached without patients and a great assistance team. Gradually, the expertise of the AMC will be diminished by the loss of experts due to retirement. Therefore, patient assistance must be provided at the AMC as frequently as possible and the effects of decentralization on science and expertise in the state must be demonstrated, or else its training and research capacities will slowly disappear. A high quality of scientific research is completely dependent on a good quality of assistance.

Finally, leprosy is an ancient disease that still has a high detection rate in remote areas, such as the State of Amazonas, and despite intense research efforts in the last centuries, it is not yet fully understood. Therefore, much progress still needs to be achieved before realistic (not statistical) elimination occurs.

\section{ACKNOWLEDGMENTS}

The work performed by the Franciscan Missionaries of Mary was the foundation of the leprosarium Colônia Antônio Aleixo and leprosy control program in the State of Amazonas. We thank Sister Maria Angela Alcalde Torrecilla on behalf of them. A special acknowledgment is addressed to the non governmental organizations for leprosy control in the State of Amazonas, including FundHans, which is funded and maintained by Maria de Fátima Maroja, Maria Angela Alcalde Torrecilla, Maria Graça Cunha and others, Deutsche Lepra-und Tuberkulosehilfe eV (DAHW), the American Leprosy Mission (ALM), and the physicians, nurses and healthcare workers from the Alfredo da Matta Center.

\section{CONFLICT OF INTEREST}

The authors declare that there is no conflict of interest.

\section{REFERENCES}

1. Britton WJ, Lockwood DN. Leprosy. Lancet 2004; 363:1209-1219.

2. Talhari S, Neves RG. Hansenologia. Manaus: Fundo Comunitário das Indústrias da Zona Franca de Manaus (FUNCOMIZ); 1984; p. 1-2.
3. Noordeen SK. The epidemiology of leprosy. In: Hastings RC, Opromolla DVA, editors. Leprosy. Edinburgh: Churchill Livingstone; 1985. p. 15-30.

4. Klatser PR, Van Beers S, Madjid B, Day R, de Wit MY. Detection of Mycobacterium leprae nasal carriers in populations for which leprosy is endemic. J Clin Microbil 1993; 31:2947-2951.

5. Desikan KV. Viability of Mycobacterium leprae outside the human body. Lepr Rev 1977; 48:231-235.

6. Rojas-Espinosa O, Løvik M. Mycobacterium leprae and Mycobacterium lepraemurium infections in domestic and wild animals. Rev Sci Tech 2001; 20:219-251.

7. Opromolla DVA. Noções de hansenologia. Bauru: Centro de Estudos Dr. Reynaldo Quagliato; 2000.

8. Talhari S, Damasco MJS, Cunha MGS, Schettini APM, Andrade LMC. Sulfono-resistência secundária (Dapsone resistance) comprovação laboratorial em seis casos. An Bras Dermatol 1985; 60:175-178.

9. World Health Organization. Chemotherapy of leprosy for control programs. WHO Tech Rep Ser 1982; 675:1-33.

10. World Health Organization. Epidemiology of leprosy in relation to control. Report of a WHO Study Group. Tech Rep Ser 1985; 716:1-60.

11. World Health Assembly. Resolution to eliminate leprosy as a public health problem by the year 2000 (resolution WHA44.9). Geneva: $44^{\text {th }}$ World Health Assembly; 1991.

12. World Health Organization. Global leprosy situation. Wkly Epidemiol Rec 2012; 87:317-328.

13. Ministério da Saúde. Secretaria de Vigilância em Saúde. Departamento de Vigilância Epidemiológica (Internet). Brasília: MS. (Cited 2013 April). Available at http://portal.saude.gov.br/ portal/saude/profissional/area.cfm?id_area $=1466 /$.

14. Penna ML, Penna GO. Trend of case detection and leprosy elimination in Brazil. Trop Med Int Health 2007; 12:647-650.

15. Secretária Estadual de Saúde, Fundação Alfredo da Matta. Boletim Epidemiológico. Número 019. Manaus: Fundação Alfredo da Matta; jan/dez. 2011. (Cited 2013 April). Available at: www.fuam.am.gov. br/arquivos/download/arqeditor/Boletim_2011.pdf

16. Monot M, Honoré N, Garnier T, Araoz R, Coppée JY, Lacroix C, et al. On the origin of leprosy. Science 2005; 308:1040-1042.

17. Souza-Araújo HC. História de lepra no Brasil: período republicano: 1889-1946: álbum das organizações antileprosas. volume II. Rio de Janeiro: Imprensa Nacional; 1948.

18. Talhari S. Contribuição ao estudo da Hanseníase na região do Alto Solimões (Amazonas-Brasil). Bol Div Dermat Sanit 1977; 1:53-62.

19. Talhari S, Aguiar AP, Matos TT, Spener S, Borborema CAT. Hanseníase no Estado do Amazonas. Histórico e desativação do Leprosário. An Bras Dermatol 1981; 56:179-84.

20. Cruz OG. Relatório sobre as condições médico-sanitárias do Valle do Amazonas, 1913. In: Sobre o saneamento da Amazonia, Manaus: P Daou; 1972. p. 144-146.

21. Matta A. Esforço histórico da lepra no estado do Amazonas. Rio de Janeiro: Sodré \& CIA; 1929.

22. Tavares T. Antônio Aleixo - de leprosário a bairro de Manaus. Manaus: Edições do Autor; 2011.

23. Superintendência de Saúde do Estado. Amazonas. Instituto de Dermatologia Tropical e Venereologia Alfredo da Matta. Instituto "Alfredo da Matta"- Ontem e hoje: uma história de saúde pública (1955-1997). Manaus: IDTVAM; 1997.

24. Matos TT. A Situação da hanseníase no Estado do Amazonas. Manaus: FIOCRUZ; 1994. 
25. Instituto Brasileiro de Geografia e Estatística (IBGE) (Internet). (Cited 2013 April). Available at: http://www.ibge.gov.br/cidadesat/ topwindow.htm?

26. Cunha MGS. Leprosy Control in Brazil - Annex (State of Amazonas). In: Yuasa Y, editor. Leprosy Profiles with special attention to MDT Implementation. SMHF/MDT Series 2. 1991; p. 84-86.

27. Talhari S, Penna GO. Independent evaluation of GAEL (Global Alliance for Leprosy Elimination). Lepr Rev 2005; 76:180-181.

28. Secretaria Estadual de Saúde, Fundação Alfredo da Matta. Boletim Epidemiológico. Número 020 Manaus: Fundação Alfredo da Matta; 2013.

29. Cole ST, Eiglmeier K, Parkhill J, James KD, Thomson NR, Wheeler PR, et al. Massive gene decay in the leprosy bacillus. Nature 2001; 409:1007-1011.
30. Mira MT, Alcaïs A, Van Thuc N, Thai VH, Huong NT, Ba NN, et al. Chromosome $6 \mathrm{q} 25$ is linked to susceptibility to leprosy in a Vietnamese population. Nat Genet 2003; 33:412-415.

31. Scollard DM. Leprosy research declines, but most of the basic questions remain unanswered. Int J Lepr 2005; 73:25-27.

32. Gelber RH, Grosset J. The chemotherapy of leprosy: an interpretive history. Lepr Rev 2012; 83:221-240.

33. Penna ML, Buhrer-Sékula S, Pontes MA, Cruz R, Gonçalves HD, Penna GO. Primary results of clinical trial for uniform multidrug therapy for leprosy patients in Brazil (U-MDT/CT-BR): reactions frequency in multibacillary patients. Lepr Rev 2012; $83: 308-319$. 